\title{
ANZTLA Board Report 2004
}

\section{by Tony McCumstie President}

Over the past twelve months, the Association has gone about its business quietly but effectively. We have continued to produce the Australasian Religion Index and our own newsletter. The annual conference has been organised and promoted and the attendance is gratifying. Chapter meetings continue to provide forums for development (both personal and professional) and networking. As with preceding years, changes have taken place in terms of library appointments, resignations and retirements but the Association continues.

The Board too has, I think, gone about its business quietly but effectively.

\section{Constitution and Board}

Judith Bright reported last year that the constitution of the newly-incorporated Association may involve some changes to the way in which the Association and particularly the Board goes about its business. Over the past twelve months, Judith and Philip Harvey have been working through the constitution to identify any areas of the Association's operations that may need to be reviewed or redefined. This task should be completed during the coming year.

\section{Conference guidelines}

Philip Harvey has prepared a set of guidelines for the organisation of an ANZTLA conference listing various elements that have gone into the planning and conducting of our conferences over the years. The purpose of the document is by no means to restrict organisers of future conferences but simply to serve as a checklist for conference committees.

\section{ARI}

During the year, the Board received a report from the ARI Management Committee on the trial ARI software. The Board unanimously adopted the recommendation of the committee and authorised ine distribution of the selected software to indexers. More detailed information on ARI can be found in the Management Committee's report.

\section{Trevor Zweck Award \& ANZTLA Consortia}

At the 1994 AGM, the Association created the Trevor Zweck Award to recognise significant contributions made by individuals to libraries and librarianship. Only one Trevor Zweck Award has been conferred since its inception. The second was conferred at the conference to Ruth Millard for her outstanding efforts in leading the ANZTLA consortia working group which has successfully negotiated three consortia. We all congratulate Ruth.

Upon re-reading the minutes of the 1994 AGM, it became apparent that the guidelines covering the award were not clear. Philip Harvey prepared revised guidelines for the Board which were considered and submitted to the Annual General Meeting for ratification.

\section{Pacific Sponsorship Scheme}

ANZTLA as an association and a number of its member libraries have longstanding ties with theological libraries in the Pacific region.

At the 1999 AGM, the Association established an "ANZTLA Pacific Sponsorship Scheme" (to be administered by the Executive/Board) under which librarians from the Pacific region could be assisted in their professional development. Following the tragically early death of Jeanette Little, it was further suggested that the scheme could be called the "Jeanette Little Fund". For various reasons, the scheme has never actually been implemented.

During the past year, Lynn Pryor prepared provisional parameters for the scheme. The Board has since considered these parameters and they were submitted to the Annual General Meeting for ratification. 


\section{Asian theological libraries}

The Board considered the possibility of broadening the scheme to include the Asian region. The general consensus was that our knowledge of and relations with Asian theological libraries are limited and that a formal sponsorship scheme covering these libraries would at this time be premature. This does not preclude the Board's or the Association's making an ad hoc decision to offer support should circumstances warrant it.

\section{Communication}

The success of an association such as ours depends very much on communication. I encourage members to keep in touch with one another through attendance at chapter meetings and annual conferences, through the ANZTLAforum and personal email and telephone conversations. It is through conversation with one another that the vitality of our association is sustained, our existing endeavours are refined and new initiatives are devised and developed.

\section{Appreciation}

In an unusual turn of events during the past year, we have seen Lynn Pryor resign as Treasurer, Catherine Halsall step into the breach (only to find that she will not be able to continue in the role) and Lynn's sole nomination for election to the position. In the April issue of the Newsletter (No. 52) I thanked Lynn for her generosity in serving the Association in a number of roles over many years. Those words stand and will be echoed at some time in the future at the completion of her encore performance.

The Board would like to express a particularly warm vote of thanks to Catherine Halsall. While her time as Treasurer was brief, the fact that Catherine did not hesitate to take on the responsibility when the position fell vacant reflects traits of generosity and commitment in Catherine that are truly admirable. We wish Catherine well in whatever comes next for her.

I thank all the members of the Board for their work and their support throughout the year. Our collective appreciation goes to the Brisbane Conference Committee for their organisation and management of this conference. Finally, I would like to thank all those members of the Association who consistently contribute their time and energy to continue the work of the association in all its endeavours.

Tony McCumstie

President (for the Board)

July 2004

\section{Jeanette Little Sponsorship Scheme}

Theological librarians from the Pacific region (not including Australia and New Zealand) are invited to apply for funding under the Jeanette Little Sponsorship Scheme.

Grants of up to $\$ 1000$ are available under the scheme for such purposes as:

- attendance at the annual conference of ANZTLA

- the purchase of professional resources

- training or education (including travel)

- expert assistance or consultancies

- introduction of new technology

Applications should be addressed to The Secretary, ANZTLA Ltd, c/- Moore Theological Library, 1 King St, Newtown NSW 2042 Australia. All letters of application should include the amount of funding sought and an explanation of how the funds will be used.

Applications for funding to attend the 2005 ANZTLA Conference must be received by 30 November 2004. 